\title{
High ammonium availability amplifies the adverse effect of low salinity on eelgrass Zostera marina
}

\author{
Beatriz Villazán1, Tiina Salo ${ }^{2,3}$, Fernando G. Brun1, Juan J. Vergara', \\ Morten F. Pedersen ${ }^{2, *}$ \\ ${ }^{1}$ Departamento de Biología (Área de Ecología), Facultad de Ciencias del Mar y Ambientales, Universidad de Cádiz, \\ Campus de Excelencia Internacional del Mar (CEIMAR), Puerto Real 11510, Cádiz, Spain \\ ${ }^{2}$ Department of Environmental, Social and Spatial Change (ENSPAC), Roskilde University, PO Box 260, 4000, Roskilde, \\ Denmark \\ ${ }^{3}$ Department of Biosciences, Åbo Akademi University, Artillerigatan 6, 20520 Åbo, Finland
}

\begin{abstract}
Climate change intensifies the frequency and intensity of rainfall events, which increases the discharge of freshwater and nutrients to coastal areas. This may lower salinity and increase nutrient availability and, thus, affect estuarine eelgrass populations. We studied the interactive effect of increasing $\mathrm{NH}_{4}{ }^{+}$levels and low salinity on estuarine eelgrass Zostera marina, grown in microcosm at various combinations of $\mathrm{NH}_{4}{ }^{+}$enrichment $(0,10$ and $25 \mu \mathrm{M})$ and salinity $(5$, 12.5 and 20). Increasing $\mathrm{NH}_{4}{ }^{+}$had a positive effect on eelgrass performance as long as salinity was kept at ambient level (20). N enrichment was followed by an increase in pigments, photosynthesis and various growth variables and a decrease in stored carbon concentrations (sucrose and starch). Low salinity had an overall negative effect on plant fitness; pigment concentration, photosynthesis and growth were reduced while mortality increased. Exposure to low salinity was also followed by a decrease in sucrose, suggesting that it was used as an osmolyte and/or that photosynthesis could not cover energy requirements needed for osmoregulation or repairing processes. Concomitant exposure to high $\mathrm{NH}_{4}{ }^{+}$and low salinity turned the positive effect of $\mathrm{NH}_{4}{ }^{+}$into a strong, negative synergistic effect. Several growth-related variables were affected significantly and mortality increased substantially. We suggest that this simultaneous exposure intensified competition for energy and $\mathrm{C}$ skeletons affecting other metabolic processes (e.g. growth, repair processes) negatively. Our results suggest that climate change driven alterations in precipitation and $\mathrm{NH}_{4}{ }^{+}$ loading might seriously impact estuarine eelgrass communities.
\end{abstract}

KEY WORDS: Carbon reserves · Dissolved inorganic nitrogen · Eutrophication · Hyposalinity · Osmoregulation $\cdot$ Seagrass

Resale or republication not permitted without written consent of the publisher

\section{INTRODUCTION}

Eelgrass Zostera marina L. is the dominant seagrass species in the Northern Hemisphere. Eelgrass is especially common in estuaries (Short et al. 2007) where it occurs at salinities ranging from 5 to 35 (den Hartog 1970). Most estuaries are influenced by substantial freshwater inputs (from precipitation, riverine run-off and point sources), which also carry large amounts of particulate and dissolved nutrients from the catchment area (Howarth et al. 1996). Ongoing climate changes have several potential consequences (e.g. rising temperatures, more frequent heat wave events, sea-level rise, higher frequency of severe storms) that may affect life in the sea. The frequency and intensity of precipitation events are predicted to increase in NW Europe and NE America (Meier et al. 2012, IPCC 2013), which is likely to 
increase the discharge of nutrient- and particle-rich freshwater to estuarine systems and, thus, potentially alter both the salinity and nutrient loads in these habitats.

Both increased nutrient loading and altered salinity regimes may affect seagrass fitness negatively and, thus, contribute to the loss of seagrass populations (Zieman 1975, Rudnick et al. 2005, Kahn \& Durako, 2006, Jiang et al. 2013). High nutrient loading causes accumulation of drift macroalgae, epiphytes and phytoplankton, which may impair light conditions for seagrasses (Sand-Jensen \& Borum 1991, McGlathery 2001, Brun et al. 2003, Lyons et al. 2012). Nutrient enrichment may further intensify the flux of organic matter to the sediment, thereby enhancing the risk of anoxia and sulphide toxicity (Holmer \& Bondgaard 2001, Borum et al. 2005, Pérez et al. 2007, Olivé et al. 2009). While relatively small increases in the availability of dissolved inorganic nitrogen (DIN) $\left(\mathrm{NH}_{4}{ }^{+}\right.$ and $\mathrm{NH}_{3}{ }^{-}$) may stimulate growth of seagrasses in pristine, oligotrophic environments (e.g. Short 1987, Powell et al. 1989, Short et al. 1990, Perez et al. 1994, Alcoverro et al. 1997), higher concentrations of $\mathrm{NH}_{4}{ }^{+}$ and $\mathrm{NH}_{3}{ }^{-}$can be toxic to seagrasses (e.g. Burkholder et al. 1992, 1994, van Katwijk et al. 1997). High availability of dissolved DIN may lead to accumulation of $\mathrm{NH}_{4}{ }^{+}$within plant cells, which can affect intracellular $\mathrm{pH}$, enzyme kinetics, photosynthetic ATP production and uptake of other ions (Marschner 1995, Britto \& Kronzucher 2002). High availability of DIN may further lead to an imbalance in the $\mathrm{C}$ economy in seagrasses because intracellular accumulation of $\mathrm{NH}_{4}{ }^{+}$ stimulates $\mathrm{N}$ assimilation (i.e. the synthesis of amino acids and proteins), which increases the need for energy and $\mathrm{C}$ skeletons and, thus, intensifies the competition with other metabolic processes for these resources (Brun et al. 2002, 2008, Villazán et al. 2013b).

Exposure to non-lethal, but sub-optimal salinity alters the ionic composition in cells, disturbs membrane integrity, affects enzyme kinetics and may thus lead to lower photosynthetic rates, growth and reproduction, and eventually increase mortality in seagrasses (Irlandi et al. 2002, Kahn \& Durako 2006, Chollett et al. 2007, Nejrup \& Pedersen 2008, Salo \& Pedersen 2014, Salo et al. 2014, Sandoval-Gil et al. 2014). Exposure to hypo- or hypersaline conditions requires osmoregulation to sustain cell turgor and a favorable ionic composition within cells. Exposure to hypo- or hypersaline conditions is therefore followed by elevated energetic expenditures related to uptake and export of ions, synthesis or breakdown of organic osmolytes and repair processes (Hellebusi 1976, Karsten 2012).
The individual effects of low salinity and $\mathrm{NH}_{4}{ }^{+}$ enrichment on seagrasses are generally well studied, whereas studies on the combined effects of multiple stressors on seagrasses are relatively rare (but see Kahn \& Durako 2006, Jiang et al. 2013, Villazán et al. 2013b, Salo \& Pedersen 2014). Marine organisms are typically exposed to more than one environmental stressor at a time and organisms are generally expected to be more sensitive to a given stressor when simultaneously affected by another (e.g. Myers 1995, Paine et al. 1998). The combined effect of 2 or more stressors may be additive or nonadditive, while non-additive effects may be synergistic or antagonistic; some studies indicate that the effects of multiple stressors on seagrasses can be synergistic (e.g. La Nafie et al. 2012, Salo \& Pedersen 2014). The possible presence of non-additive effects of multiple stressors makes it difficult to predict consequences of ongoing climate changes on seagrasses because these changes are expected to alter several environmental and potentially stressful factors at the same time (e.g. temperature, light conditions, salinity, nutrient availability). If the combined effect of multiple stressors is synergistic then the predictions based on the impact of single stressors (i.e. assuming additive effects) will underestimate the total effect of changes in these stressors (Darling \& Côté 2008).

Estuarine seagrasses are exposed to short- and long-term variations in both salinity and $\mathrm{NH}_{4}{ }^{+}$concentration, and ongoing climate change is expected to increase fluctuations in these variables, which will likely alter the level of stress (strength and duration) imposed on these organisms. It is therefore valuable to study potential interactive effects between environmental factors that may stress eelgrass. We hypothesize that stress imposed by low salinity and high $\mathrm{NH}_{4}^{+}$availability will lead to an increased competition for energy and carbon within plants and we expect these to have either additive or synergistic impacts on plant fitness. We tested therefore if low salinity enhanced the expected adverse effect of $\mathrm{NH}_{4}{ }^{+}$enrichment in eelgrass in a factorial experiment with 3 levels of $\mathrm{NH}_{4}{ }^{+}$availability (target concentrations: 0,10 and $25 \mu \mathrm{M}$ ) and 3 levels of salinity $(5,12.5$ and 20) using a range of physiological response variables (e.g. photosynthesis, pigment concentrations, growth, survival, nutrient uptake rates) that are indicators of plant fitness. In addition, we measured intracellular concentrations of total $\mathrm{N}$, $\mathrm{NH}_{4}{ }^{+}, \mathrm{Na}^{+}, \mathrm{K}^{+}, \mathrm{Cl}^{-}$and non-structural carbohydrates to investigate the underlying mechanisms for the observed physiological responses. 


\section{MATERIALS AND METHODS}

\section{Experimental setup}

A 2-factorial aquaria experiment was conducted during October and November 2012 to test how $\mathrm{NH}_{4}{ }^{+}$ availability and salinity affected eelgrass response. Eelgrass shoots were collected from Isefjorden $\left(55^{\circ} 42^{\prime} 44^{\prime \prime} \mathrm{N}, 11^{\circ} 47^{\prime} 35^{\prime \prime} \mathrm{E}\right)$, Denmark, at a depth of 0.5 to $1 \mathrm{~m}$ at the beginning of October 2012. Water temperature at the sampling site was ca. $16^{\circ} \mathrm{C}$ and salinity was ca. 20. Healthy looking shoots with intact rhizomes and roots were transferred to the laboratory where they were kept for 2 to $3 \mathrm{~d}$ in aerated seawater under sub-saturating light (ca. $30 \mu \mathrm{mol}$ photons $\mathrm{m}^{-2}$ $\mathrm{s}^{-1}$ ) at $15^{\circ} \mathrm{C}$. Shoots were standardized to have 3 to 4 (visible) leaves and 3 rhizome internodes (by removing older leaves and rhizome internodes) prior to the experiment. 27 aquaria (volume $=201$ ) were filled with 2 to $3 \mathrm{l}$ of sediment from the Isefjord and $15 \mathrm{l}$ of water with salinity of 20 mixed from seawater (salinity 30 ) and tap water.

Twelve haphazardly chosen eelgrass shoots were planted in each of the 27 aquaria, which were then subjected to a factorial design with 3 target concentrations of $\mathrm{NH}_{4}{ }^{+}(0,10$ and $25 \mu \mathrm{M}$; treatments hereafter called 'control', $+\mathrm{N}$ and $+\mathrm{NN}$, respectively) and 3 levels of salinity (5, 12.5 and 20), with 3 replicate aquaria in each treatment combination. Target levels of salinity in the aquaria were obtained by lowering the salinity by ca. 3 units every second day. The first pulse of $\mathrm{NH}_{4}{ }^{+}$was added $3 \mathrm{~d}$ after the target levels of salinity were reached in all the aquaria.

The water used in the experiment contained low levels of $\mathrm{NH}_{4}^{+}$(ca. $0.5 \mu \mathrm{M}$ ). Additional $\mathrm{NH}_{4}^{+}$was added to the aquaria (in the $+\mathrm{N}$ and $+\mathrm{NN}$ treatments) from an $\mathrm{NH}_{4} \mathrm{Cl}$ stock-solution every day. Concentrations of $\mathrm{NH}_{4}{ }^{+}$were selected to correspond to those in a previous study on $\mathrm{NH}_{4}{ }^{+}$effects on eelgrass (Villazán et al. 2013b). The daily loading of $\mathrm{NH}_{4}^{+}$ to each aquaria corresponded to 0 $\mu \mathrm{mol}$ in the control treatment, 150 $\mu \mathrm{mol} \mathrm{d} \mathrm{d}^{-1}$ in the $+\mathrm{N}$ treatment and 375 $\mu \mathrm{mol} \mathrm{d}^{-1}$ in the $+\mathrm{NN}$ treatment, respectively. Concentrations of $\mathrm{NH}_{4}{ }^{+}$ were measured twice weekly in all aquaria; water samples were collected before and after nutrient additions and analyzed in accordance with Bower \& Holm-Hansen (1980).
The concentration of $\mathrm{NH}_{4}{ }^{+}$in water before adding a new pulse of $\mathrm{NH}_{4}{ }^{+}$was close to zero in most treatments (Table 1), although accumulation of $\mathrm{NH}_{4}{ }^{+}$was observed in aquaria from the low salinity (5) to the high $\mathrm{N}(25 \mu \mathrm{M})$ treatment (Table 1$)$. The experiment lasted for $4 \mathrm{wk}$ after the first $\mathrm{NH}_{4}{ }^{+}$addition.

Dissolved inorganic carbon (DIC) concentrations in the water were measured twice (2nd and 4 th week) in all aquaria by Gran titration. DIC concentrations averaged $3.37 \pm 0.06 \mathrm{mM}$ (mean $\pm \mathrm{SE}$ ), across 3 replicate aquaria and over 2 sampling dates in each of the 9 treatment combinations, which is high enough to saturate DIC uptake and photosynthesis in eelgrass (Sand-Jensen \& Gordon 1984). Light intensity above the aquaria was close to the saturating level for growth (ca. $80 \mu \mathrm{mol}$ photons $\mathrm{m}^{-2} \mathrm{~s}^{-1}$; Olesen \& SandJensen 1993) and was provided by halogen lamps $(12 \mathrm{~V}, 35 \mathrm{~W})$ in a 16:8 h light:dark cycle. Water temperature was kept constant at $15^{\circ} \mathrm{C}$ to obtain optimal growth conditions (Nejrup \& Pedersen 2008). The water was aerated to ensure mixing and about half the volume in each aquarium was changed weekly to reduce the risk of $\mathrm{C}$, phosphorus and/or micronutrient limitation and to prevent growth of epiphytes.

\section{Physiological and morphological responses}

Maximum net photosynthetic rate $\left(P_{\max }\right)$ and dark respiration was measured as $\mathrm{O}_{2}$ production and consumption under saturating light and in darkness, respectively. At the conclusion of the experiment (during the last week) 2 randomly chosen shoots from each aquarium were incubated in an $800 \mathrm{ml}$ gas-tight, transparent chamber equipped with a circulation pump (AquaBee, $300 \mathrm{l} \mathrm{h}^{-1}$ ) to ensure

Table 1. Average ammonium concentrations $(\mu \mathrm{M})$ in aquaria over the course of the experiment to study the interactive effect of increasing $\mathrm{NH}_{4}{ }^{+}$levels and low salinity on estuarine eelgrass Zostera marina. Target concentrations of $\mathrm{NH}_{4}{ }^{+}$were $0 \mu \mathrm{M}$ (control), $10 \mu \mathrm{M}(+\mathrm{N})$ and $25 \mu \mathrm{M}(+\mathrm{NN})$. Samples for these measurements were taken before and after adding new ammonium in each treatment combination. $\mathrm{NH}_{4}{ }^{+}$values are shown as mean $\pm 1 \mathrm{SE}$ across 3 replicate aquaria and over 16 sampling events in each treatment

\begin{tabular}{|lcrrr|}
\hline \multirow{2}{*}{ Sampling time } & Salinity & \multicolumn{3}{c|}{$\mathrm{NH}_{4}{ }^{+}(\mu \mathrm{M})$} \\
\cline { 3 - 5 } & & Control & $+\mathrm{N}$ & \multicolumn{1}{c}{$+\mathrm{NN}$} \\
\hline Prior to adding $\mathrm{NH}_{4}{ }^{+}$ & 20 & $0.35 \pm 0.12$ & $0.39 \pm 0.20$ & $2.58 \pm 1.22$ \\
& 12.5 & $0.43 \pm 0.13$ & $0.70 \pm 0.29$ & $4.84 \pm 1.41$ \\
& 5 & $0.09 \pm 0.07$ & $1.29 \pm 0.44$ & $15.81 \pm 3.20$ \\
After adding $\mathrm{NH}_{4}{ }^{+}$ & 20 & $0.35 \pm 0.12$ & $9.95 \pm 0.48$ & $25.90 \pm 1.45$ \\
& 12.5 & $0.24 \pm 0.22$ & $10.82 \pm 0.30$ & $29.10 \pm 1.68$ \\
& 5 & $0.10 \pm 0.07$ & $12.52 \pm 0.92$ & $41.62 \pm 4.09$ \\
\hline
\end{tabular}


water movement within the chamber. The chamber was filled with seawater (salinity corresponding to that in the respective aquaria). To prevent $\mathrm{O}_{2}$ saturation in the chambers during incubations, the $\mathrm{O}_{2}$ level of the water was reduced to ca. $70 \%$ of air saturation by bubbling with gaseous $\mathrm{N}_{2}$. The chamber was finally submerged into a water bath at constant temperature $\left(15^{\circ} \mathrm{C}\right)$ and equipped with a Clark-type $\mathrm{O}_{2}$ microelectrode (OX-500, Unisense) connected to a pico-amperimeter (Picoammeter PA2000, Unisense) and to a data logger (ADC-16, Pico Technology). A lamp with 8 halogen spots (OSRAM Decostar 51; $12 \mathrm{~V}, 35 \mathrm{~W}$ ) illuminated the set-up $\left(375 \mu \mathrm{mol}\right.$ photons $\mathrm{m}^{-2} \mathrm{~s}^{-1}$ ) for the $P_{\max }$ measurements. The $\mathrm{O}_{2}$ concentrations were recorded every minute and rates of $\mathrm{O}_{2}$ release or consumption (mg $\mathrm{O}_{2} \mathrm{~g}^{-1}$ dry weight $[\mathrm{DW}] \mathrm{h}^{-1}$ ) were calculated from periods with a constant change in $\mathrm{O}_{2}$ concentration over a minimum of $15 \mathrm{~min}$.

Chlorophyll fluorescence was measured using PAM fluorometry (Hansatech Instruments). Maximum quantum yield $\left(F_{\mathrm{v}} / F_{\mathrm{m}}\right)$ of photosystem II was measured on 3 randomly selected and dark-adapted (15 min) plants from each aquarium.

Fresh biomass of each plant was measured at the start and at the end of the experiment. Net production (NP; $g$ fresh weight $[\mathrm{FW}]$ plant $^{-1} \mathrm{~d}^{-1}$ ) was estimated from net changes in individual plant weights (FW) over the course of the experiment. Leaf elongation rate (LER) was measured using the plastochrone interval technique, as described by SandJensen (1975). Appearance of new internodes per shoot (IAR) was recorded, and mortality rates were determined from the final number of dead plants in each aquarium at the end of the experiment. Leaf necrosis was estimated as the proportion of dark brown or black colored leaf tissue in the first 3 leaves of each shoot in accordance with van Katwijk et al. (1997).

\section{Nutrient uptake rates}

Uptake rates of $\mathrm{PO}_{4}{ }^{3-}$ and $\mathrm{NH}_{4}{ }^{+}$were measured on whole eelgrass shoots with attached roots and rhizomes using the perturbation method (Pedersen 1994) during the last week of the experiment. Two randomly selected plants from each aquarium were introduced into a glass chamber containing 11 of seawater with the same salinity as in the respective treatment. Chambers were kept at $15^{\circ} \mathrm{C}$ and the water in each chamber was bubbled with air to ensure mixing and to reduce boundary layer effects.
Nutrients $\left(\mathrm{NH}_{4}{ }^{+}\right.$or $\left.\mathrm{PO}_{4}{ }^{3-}\right)$ were added to each chamber from stock solutions $\left(\mathrm{NH}_{4} \mathrm{Cl}\right.$ or $\mathrm{KH}_{2} \mathrm{PO}_{4}$, respectively) to obtain initial concentrations of $25 \mu \mathrm{M}$ of $\mathrm{NH}_{4}{ }^{+}$or $8 \mu \mathrm{M}$ of $\mathrm{PO}_{4}{ }^{3-}$. Triplicate water samples were taken after 0 and $120 \mathrm{~min}$, respectively. Incubation time was selected according to the existing literature on seagrass nutrient uptake, where $120 \mathrm{~min}$ is often used to avoid nutrient depletion in the culture medium (Touchette \& Burkholder 2000, Villazán et al. 2013a).

Concentrations of $\mathrm{NH}_{4}{ }^{+}$and $\mathrm{PO}_{4}{ }^{3-}$ were analyzed immediately in accordance with Bower \& HolmHansen (1980) and Murphy \& Riley (1962), respectively. At the end of each uptake measurement, plants were weighed $(\mathrm{FW})$ and returned to their aquaria. Nutrient uptake rates $\left(V, \mu \mathrm{mol} \mathrm{g}{ }^{-1} \mathrm{FW} \mathrm{h}^{-1}\right)$ were estimated from changes in nutrient concentration $(S)$ over the course of the incubation using Eq. (1), where $S_{0}$ and $\operatorname{vol}_{0}$ are the initial nutrient concentration and water volume, $S_{\mathrm{f}}$ and $\mathrm{vol}_{\mathrm{f}}$ are the final nutrient concentration and water volume, respectively, and $t$ is the time elapsed between sampling events.

$$
V=\frac{\left(S_{0} \times \operatorname{vol}_{0}\right)-\left(S_{\mathrm{f}} \times \operatorname{vol}_{\mathrm{f}}\right)}{(t \times \mathrm{FW})}
$$

\section{Biochemical responses}

Biochemical responses were analyzed at the end of the experiment. Chlorophyll $\mathrm{a}_{\mathrm{a}+\mathrm{b}}$ concentrations were determined on duplicate leaf samples from each aquarium. Samples were freeze-dried to constant weight (i.e. DW), ground and extracted overnight in $96 \%$ ethanol. The extractant was homogenized and filtered before determining the chlorophyll concentrations spectrophotometrically at 665 and $649 \mathrm{~nm}$ (Wintermans \& DeMotts 1965). Total $\mathrm{N}$ content was determined on duplicate freeze-dried and ground samples of leaves from each aquarium using a Carlo-Erba NA-1500 CNS analyzer.

Intracellular concentrations of inorganic ions $\left(\mathrm{NH}_{4}{ }^{+}, \mathrm{Na}^{+}, \mathrm{K}^{+}\right.$and $\left.\mathrm{Cl}^{-}\right)$were determined in leaf samples from one randomly selected plant from each aquarium. Leaves were cleaned for epiphytes and salts using MilliQ water, dried to constant weight at $60^{\circ} \mathrm{C}$ and ground. The plant material was dissolved in $15 \mathrm{ml}$ of $3.5 \mathrm{mM} \mathrm{HNO}_{3}$, stirred for $30 \mathrm{~min}$ and subsequently centrifuged at $2000 \times g$ for $5 \mathrm{~min}$. The supernatant was passed through a $0.45 \mu \mathrm{m}$ filter and concentrations of $\mathrm{NH}_{4}{ }^{+}, \mathrm{Na}^{+}, \mathrm{K}^{+}$ 
and $\mathrm{Cl}^{-}$were finally analyzed using an ion chromatograph (Metrohm 850 ProflC AnCat-MCS) with chemical suppression and conductimetric detection (Marín-Guirao et al. 2013).

Concentrations of sucrose and starch were measured on triplicate, freeze-dried and ground leaf and root/rhizome samples from each aquarium. Total non-structural carbohydrates (TNC) were measured following Brun et al. (2002). Sugars (sucrose and hexoses) were first solubilized by 4 sequential extractions in $96 \%(\mathrm{v} / \mathrm{v})$ ethanol at $80^{\circ} \mathrm{C}$ for $15 \mathrm{~min}$. Ethanol extracts were evaporated and residues were dissolved in deionized water for analysis. Starch was extracted from the ethanolinsoluble residues by incubation in $1 \mathrm{~N} \mathrm{NaOH}$ for $24 \mathrm{~h}$. Sucrose and starch contents of extracts were determined spectrophotometrically using resorcinol and anthrone assays at 486 and $640 \mathrm{~nm}$, respectively, with sucrose as a standard.

\section{Statistical analysis}

The experiment was originally designed as a 2 -factorial experiment with categorical factors salinity and $\mathrm{NH}_{4}{ }^{+}$treatments. However, we were unable to keep $\mathrm{NH}_{4}{ }^{+}$concentrations constant (across levels of salinity within each category of $\mathrm{NH}_{4}{ }^{+}$) so we decided to treat $\mathrm{NH}_{4}{ }^{+}$treatment as a continuous (i.e. covariate) variable. We used therefore permutational ANCOVA with one continuous variable $\left(\mathrm{NH}_{4}{ }^{+}\right.$concentration) and 1 (salinity) or 2 (salinity and plant part) categorical variables to analyze the data. Analyses were conducted with the PERMANOVA package in PRIMER+ v. 6 (Anderson et al. 2008). Categorical factors were considered fixed and all response data and the covariate (i.e. average $\mathrm{NH}_{4}{ }^{+}$ concentration in each aquarium) were $\log (x+1)$ transformed prior to analysis to increase linearity between the response and $\mathrm{NH}_{4}{ }^{+}$concentration. Resemblance matrixes were based on Euclidean distances and the analyses were conducted using Type I SS with 9999 permutations under a reduced model (Anderson et al. 2008). MDS plots and PERMDISP were used to inspect the dispersion of the data. All tests were carried out using $\alpha=0.05$.

Permutational multivariate ANCOVA was first used to test the overall effect of $\mathrm{NH}_{4}{ }^{+}$enrichment and salinity on all physiological and morphological variables, i.e. $P_{\max }$ respiration, $F_{\mathrm{v}} / F_{\mathrm{m}}$, leaf elongation, number of new internodes, number of standing leaves, net production, necrosis, mortality and nutrient $\left(\mathrm{PO}_{4}{ }^{3-}\right.$ and $\left.\mathrm{NH}_{4}{ }^{+}\right)$uptake rates. Data were nor- malized prior to analysis to minimize scale differences among response variables. The multivariate approach was chosen because many of the measured response variables were likely inter-correlated. The effect of treatment factors on each individual response variable was subsequently analyzed using univariate 1-factor ANCOVA as recommended by Quinn \& Keough (2002). For sucrose and starch, we used univariate 2-factor ANCOVA including plant parts (i.e. leaves and roots/rhizomes) as a second categorical factor.

A significant interaction in the ANCOVA analyses mentioned above indicates a non-additive (i.e. synergistic or antagonistic) effect and we tested therefore whether combined stress imposed by low salinity and high ammonium was additive or nonadditive. We did so for the physiological and morphological response variables in Table 2 (below) by estimating the relative response ratio (RR) for each variable as:

$$
\mathrm{RR}=\frac{\text { Stress treatment }- \text { Non-stressed }}{\text { Non-stressed }}
$$

where 'Stress treatment' and 'Non-stressed' are the measured mean responses in the stress treatments (i.e. low salinity, high $\mathrm{N}$ and the combination of low salinity and high $\mathrm{N}$, respectively) and the non-stressed situation (i.e. high salinity and low $\mathrm{N})$, respectively. We used an additive null model as the combined stressor expectation (Darling \& Côté 2008):

$$
\mathrm{RR}_{\text {Additive }}=\mathrm{RR}_{\text {Stressor 1 }}+\mathrm{RR}_{\text {Stressor } 2}
$$

The relative responses were calculated as combinations of individual variables, each measured with their own error and the bootstrap procedure (Efron \& Tibshirani 1986) was therefore used to estimate means and confidence intervals of each response variable. Bootstrap means and confidence intervals were computed for each response variable by first resampling 1500 values among the original data for each parameter. Each set of drawn numbers was then combined to estimate relative responses using Eqs. (2) \& (3). The 1500 resulting estimates were then organized into 500 data sets, each with $n=3$ as in the original data and means were estimated for each. The 500 new mean values were finally used to estimate bootstrap means and $95 \%$ confidence intervals for each response variable. Confidence intervals were estimated from the 2.5 and 97.5 percentiles of the 500 means obtained by permutation (Meyer et al. 1986). 


\section{RESULTS}

\section{Physiological and morphological variables}

The multivariate response of all physiological and morphological variables was affected by the interaction between $\mathrm{NH}_{4}{ }^{+}$and salinity (Table 2). Enrichment with $\mathrm{NH}_{4}{ }^{+}$had an effect on the multivariate response at salinity 20 , but not at 12.5 and 5 . High $\mathrm{NH}_{4}{ }^{+}$loading altered most of the individual response variables negatively at salinity 5 , whereas there was no clear or even a positive effect of $\mathrm{NH}_{4}{ }^{+}$enrichment at higher salinities.

$P_{\max }$ was affected by the interaction between $\mathrm{NH}_{4}{ }^{+}$ and salinity (Fig. 1A, Table 2). $P_{\max }$ was unaffected by $\mathrm{NH}_{4}{ }^{+}$at salinity 5 and 12.5 , but increased from 1.63 to $5.26 \mathrm{mg} \mathrm{O}_{2} \mathrm{~g}^{-1} \mathrm{DW} \mathrm{h}{ }^{-1}$ with increasing $\mathrm{NH}_{4}{ }^{+}$concentration at salinity 20 . Subsequent analysis showed that the combined effect of both stressors was synergistic (Table 3$)$. Dark respiration rate $\left(R_{\mathrm{D}}\right)$ was influenced by salinity, but not by $\mathrm{NH}_{4}{ }^{+}$(Table 2, Fig. 1A), being significantly higher at salinity 5 than at 12.5 and 20 . $F_{\mathrm{v}} / F_{\mathrm{m}}$ was only affected by salinity (Table 2 ), being lower at salinity 5 than at 12.5 and 20 (Fig. 1B).

The interaction between $\mathrm{NH}_{4}{ }^{+}$and salinity affected leaf elongation rate (Table 2), which was reduced by ca. $50 \%$ with increasing $\mathrm{NH}_{4}{ }^{+}$at low salinity, but increased with increasing $\mathrm{NH}_{4}{ }^{+}$-loading at salinities 12.5 and 20 (Fig. 1C). The combined effect of low salinity and high $\mathrm{NH}_{4}{ }^{+}$was synergistic (Table 3). Internode appearance rate (IAR) was only affected significantly by salinity (Fig. 1D, Table 2), being lower at salinity 5 than at 12.5 and 20 . The final number of leaves per shoot was affected by the interaction between $\mathrm{NH}_{4}{ }^{+}$and salinity (Fig. 1E, Table 2) and the combined effect was synergistic (Table 3): plants had less leaves per shoot at salinity 5 and the number decreased with increasing $\mathrm{NH}_{4}{ }^{+}$load. No effect of $\mathrm{NH}_{4}{ }^{+}$ was evident at salinity 12.5 and 20 . Net production was affected by the interaction between $\mathrm{NH}_{4}{ }^{+}$and salinity (Fig. 1F, Table 2), being low and decreasing with increasing $\mathrm{NH}_{4}{ }^{+}$(from $8 \mathrm{~g} \mathrm{FW}$ plant ${ }^{-1} \mathrm{~d}^{-1}$ in the control to ca. $2 \mathrm{~g} \mathrm{FW}$ plant ${ }^{-1} \mathrm{~d}^{-1}$ in the $+\mathrm{NN}$ treatment) at low salinity, but increasing slightly with increasing $\mathrm{NH}_{4}{ }^{+}$-load at salinities 12.5 and 20 (Fig. 1F). The combined effect of low salinity and high $\mathrm{NH}_{4}{ }^{+}$was synergistic (Table 3). Necrosis was affected by salinity, being more widespread at salinity 5 than at 12.5 and 20 . Necrosis was not affected by $\mathrm{NH}_{4}{ }^{+}$, nor by the interaction between $\mathrm{NH}_{4}{ }^{+}$and salinity (Fig. 1G, Table 2). Mortality was influenced by both $\mathrm{NH}_{4}{ }^{+}$and salinity (Fig. 1H, Table 2) being close to 0 at salinity 20 across all $\mathrm{NH}_{4}{ }^{+}$-treatments, but increasing with $\mathrm{NH}_{4}{ }^{+}$en-
Table 2. Results of multivariate and univariate permutational ANCOVA analyses examining the effects of salinity (S) (categorical variable) and ammonium concentration (N) (continuous variable) on physiological and morphological responses of eelgrass Zostera marina. $P_{\max }$ photosynthetic rate; $F_{\mathrm{v}} / F_{\mathrm{m}}$ : maximum quantum yield; LER: leaf elongation rate; IAR: internode appearance rate; NP: net production. Bold p-values indicate significant results $(\alpha=0.05)$

\begin{tabular}{|c|c|c|c|c|}
\hline Variable, factors & df & MS & Pseudo- $F$ & $\mathrm{p}$ \\
\hline \multicolumn{5}{|c|}{ Multivariate response } \\
\hline $\mathrm{N}$ & 1 & 38.62 & 9.71 & $<0.001$ \\
\hline $\mathrm{S}$ & 2 & 67.65 & 17.01 & $<0.001$ \\
\hline $\mathrm{N} \times \mathrm{S}$ & 2 & 14.28 & 3.59 & $<0.001$ \\
\hline Residual & 21 & 3.98 & & \\
\hline \multicolumn{5}{|c|}{ Univariate responses } \\
\hline \multicolumn{5}{|c|}{$\boldsymbol{P}_{\max }$} \\
\hline $\mathrm{S}$ & 2 & $4.98 \times 10^{-2}$ & 7.63 & 0.003 \\
\hline $\mathrm{N} \times \mathrm{S}$ & 2 & $6.17 \times 10^{-2}$ & 9.45 & 0.001 \\
\hline Residual & 21 & $6.53 \times 10^{-3}$ & & \\
\hline \multicolumn{5}{|l|}{ Respiration rate } \\
\hline $\mathrm{N}$ & 1 & $4.84 \times 10^{-4}$ & 0.05 & 0.835 \\
\hline $\mathrm{S}$ & 2 & $5.62 \times 10^{-2}$ & 5.50 & 0.012 \\
\hline $\mathrm{N} \times \mathrm{S}$ & 2 & $5.29 \times 10^{-3}$ & 0.52 & 0.603 \\
\hline Residual & 21 & $1.02 \times 10^{-2}$ & & \\
\hline \multicolumn{5}{|l|}{$F_{\mathrm{v}} / F_{\mathrm{m}}$} \\
\hline & 1 & $1.00 \times 10^{-4}$ & 0.43 & 0.488 \\
\hline $\mathrm{S}$ & 2 & $1.49 \times 10^{-3}$ & 7.33 & 0.005 \\
\hline $\mathrm{N} \times \mathrm{S}$ & 2 & $7.23 \times 10^{-5}$ & 0.36 & 0.704 \\
\hline Residual & 21 & $2.03 \times 10^{-4}$ & & \\
\hline \multicolumn{5}{|l|}{ LER } \\
\hline $\mathrm{N}$ & 1 & $1.10 \times 10^{-2}$ & 11.71 & 0.003 \\
\hline $\mathrm{S}$ & 2 & 0.27 & 187.70 & $<0.001$ \\
\hline $\mathrm{N} \times \mathrm{S}$ & 2 & $3.29 \times 10^{-2}$ & 35.11 & $<0.001$ \\
\hline Residual & 21 & $9.37 \times 10^{-4}$ & & \\
\hline \multicolumn{5}{|l|}{ IAR } \\
\hline $\mathrm{N}$ & 1 & $3.94 \times 10^{-5}$ & 0.79 & 0.391 \\
\hline $\mathrm{S}$ & 2 & $7.60 \times 10^{-4}$ & 15.17 & $<0.001$ \\
\hline $\mathrm{N} \times \mathrm{S}$ & 2 & $1.54 \times 10^{-4}$ & 3.06 & 0.066 \\
\hline Residual & 21 & $5.01 \times 10^{-5}$ & & \\
\hline \multicolumn{5}{|l|}{ No. of leaves } \\
\hline $\mathrm{N}$ & 1 & $1.63 \times 10^{-3}$ & 1.73 & 0.198 \\
\hline $\mathrm{S}$ & 2 & $5.55 \times 10^{-2}$ & 58.99 & $<0.001$ \\
\hline $\mathrm{N} \times \mathrm{S}$ & 2 & $7.94 \times 10^{-3}$ & 8.44 & 0.001 \\
\hline Residual & 21 & $9.41 \times 10^{-4}$ & & \\
\hline \multicolumn{5}{|l|}{ NP } \\
\hline $\mathrm{N}$ & 1 & $2.83 \times 10^{-6}$ & 2.52 & 0.127 \\
\hline $\mathrm{S}$ & 2 & $1.02 \times 10^{-4}$ & 91.01 & $<0.001$ \\
\hline $\mathrm{N} \times \mathrm{S}$ & 2 & $2.30 \times 10^{-5}$ & 20.44 & $<0.001$ \\
\hline Residual & 21 & $1.12 \times 10^{-6}$ & & \\
\hline \multicolumn{5}{|l|}{ Necrosis } \\
\hline $\mathrm{N}$ & 1 & $7.80 \times 10^{-2}$ & 2.16 & 0.160 \\
\hline $\mathrm{S}$ & 2 & 1.54 & 42.67 & $<0.000$ \\
\hline $\mathrm{N} \times \mathrm{S}$ & 2 & $6.93 \times 10^{-2}$ & 1.92 & 0.166 \\
\hline Residual & 21 & $3.60 \times 10^{-2}$ & & \\
\hline \multicolumn{5}{|l|}{ Mortality } \\
\hline $\mathrm{N}$ & 1 & 2.20 & 15.09 & $<0.001$ \\
\hline $\mathrm{S}$ & 2 & 1.18 & 8.10 & 0.002 \\
\hline $\mathrm{N} \times \mathrm{S}$ & 2 & 0.26 & 1.80 & 0.192 \\
\hline Residual & 21 & 0.15 & & \\
\hline \multicolumn{5}{|l|}{$\mathrm{NH}_{4}{ }^{+}$uptake rate } \\
\hline $\mathrm{N}$ & 1 & 0.25 & 44.20 & $<0.001$ \\
\hline $\mathrm{S}$ & 2 & $5.30 \times 10^{-2}$ & 9.19 & 0.001 \\
\hline $\mathrm{N} \times \mathrm{S}$ & 2 & $6.63 \times 10^{-3}$ & 1.15 & 0.330 \\
\hline Residual & 21 & $5.77 \times 10^{-3}$ & & \\
\hline \multicolumn{5}{|l|}{$\mathrm{PO}_{4}{ }^{3-}$ uptake rate } \\
\hline $\mathrm{N}$ & 1 & $7.66 \times 10^{-2}$ & 29.09 & $<0.001$ \\
\hline $\mathrm{S}$ & 2 & $1.26 \times 10^{-2}$ & 4.79 & 0.019 \\
\hline $\mathrm{N} \times \mathrm{S}$ & 2 & $1.60 \times 10^{-2}$ & 6.09 & 0.010 \\
\hline Residual & 21 & $2.63 \times 10^{-3}$ & & \\
\hline
\end{tabular}



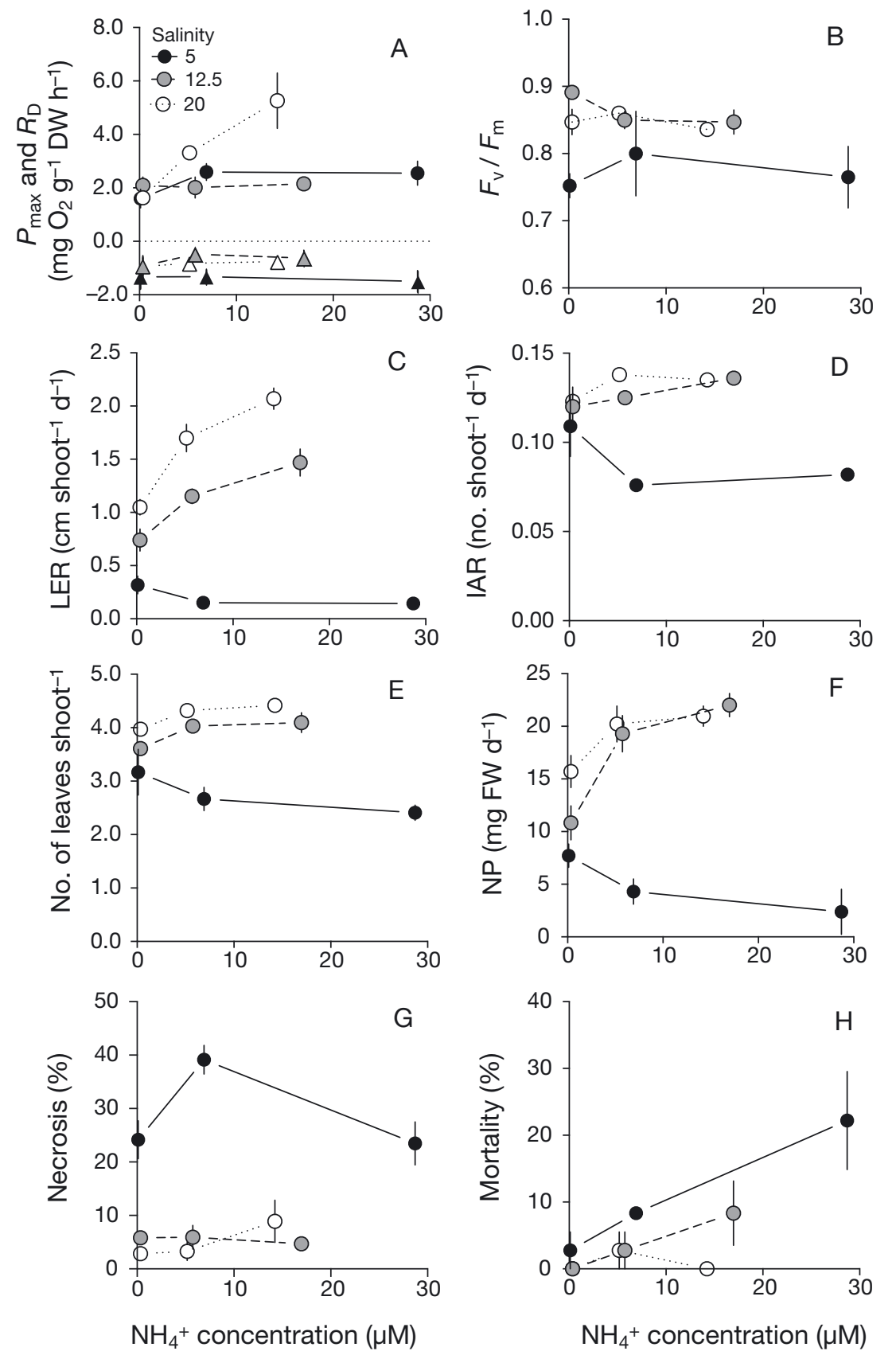

Fig. 1. Zostera marina. Physiological and morphological variables of eelgrass plants exposed to 3 levels of salinity $\left(5,12.5\right.$ and 20) and 3 levels of $\mathrm{NH}_{4}{ }^{+}:$(A) maximum photosynthetic rate $\left(P_{\max }\right.$, circles) and dark respiration rate $\left(R_{\mathrm{D}}\right.$, triangles); (B) maximum quantum yield $\left(F_{\mathrm{v}} / F_{\mathrm{m}}\right) ;(\mathrm{C})$ leaf elongation rate (LER); (D) internode appearance rate (IAR); (E) number of leaves per shoot; $(\mathrm{F})$ net production $(\mathrm{NP}) ;(\mathrm{G})$ degree of necrosis ; $(\mathrm{H})$ mortality. Values are means (across 3 replicate aquaria) $\pm 1 \mathrm{SE}$

richment at salinities 12.5 and 5. Subsequent analysis suggested that the combined effect of low salinity and high $\mathrm{NH}_{4}{ }^{+}$was synergistic (Table 3 ) although this was not supported by a significant interaction in the ANCOVA analysis (Table 2).

\section{Nutrient uptake rates}

Uptake rates of $\mathrm{NH}_{4}{ }^{+}$were affected by both factors $\left(\mathrm{NH}_{4}{ }^{+}\right.$and salinity), but not by their interaction (Table 2, Fig. 2A). Low salinity had a negative effect on $\mathrm{NH}_{4}{ }^{+}$uptake rate, which also decreased with increasing levels of the $\mathrm{NH}_{4}{ }^{+}$treatments, being ca. $50 \%$ lower in the $+\mathrm{NN}$ treatment than in the control. In contrast, $\mathrm{PO}_{4}{ }^{3-}$ uptake rates (Fig. 2B) decreased with decreasing salinity and increased with $\mathrm{NH}_{4}{ }^{+}$enrichment, except at low salinity where uptake rate remained unaffected by $\mathrm{NH}_{4}{ }^{+}$level, which resulted in a significant interaction between salinity and $\mathrm{NH}_{4}{ }^{+}$treatment (Table 2). The effect of low salinity and high $\mathrm{NH}_{4}{ }^{+}$was synergistic according to the results in Table 3.

\section{Biochemical responses}

Chlorophyll $_{\mathrm{a}+\mathrm{b}}$ content was affected by both the $\mathrm{NH}_{4}{ }^{+}$and the salinity treatments, but not by their interaction (Fig. 3A, Table 4). Low salinity led to lower levels of chlorophyll $a+b$ while increasing $\mathrm{NH}_{4}{ }^{+}$levels were followed by an overall increase in chlorophyll ${ }_{\mathrm{a}+\mathrm{b}}$ content.

Total $\mathrm{N}$ content was only affected by the $\mathrm{NH}_{4}{ }^{+}$treatment (Fig. 3B, Table 4) and increased with $\mathrm{NH}_{4}{ }^{+}$loading. The concentration of intracellular $\mathrm{NH}_{4}{ }^{+}$ (Fig. 3C) followed the same pattern: it was significantly affected by $\mathrm{NH}_{4}{ }^{+}$, but not by salinity and nor by the interaction between $\mathrm{NH}_{4}{ }^{+}$and salinity (Table 4).

The interaction between $\mathrm{NH}_{4}{ }^{+}$and salinity had a significant effect on the concentrations of $\mathrm{Na}^{+}, \mathrm{K}^{+}$and $\mathrm{Cl}^{-}$ (Fig. 4, Table 4). The concentration of $\mathrm{Na}^{+}$(Fig. 4A) and $\mathrm{K}^{+}$(Fig. 4B) increased with increasing $\mathrm{NH}_{4}{ }^{+}$loading at salinity 20, were largely unaffected by $\mathrm{NH}_{4}{ }^{+}$at salinity 12.5 and decreased slightly with increasing $\mathrm{NH}_{4}{ }^{+}$-loading at salinity 5 . The concentration of $\mathrm{Cl}^{-}$ (Fig. 4C) increased with increasing $\mathrm{NH}_{4}{ }^{+}$at salinity 12.5 and 20, respectively, but was unaffected by 
Table 3. Zostera marina. Relative response ratios (Eq. 2) of growth-related response variables (Table 2) in eelgrass plants when exposed to low salinity alone, to high $\mathrm{N}$ availability alone and to the combination of low salinity and high $\mathrm{N}$ availability. The estimated additive effect is the null model to which the combined response is tested. Values shown are adjusted bootstrap means and $95 \%$ confidence interval (in brackets). For abbreviations see Table 1 legend

\begin{tabular}{|c|c|c|c|c|c|}
\hline Variable & $\begin{array}{l}\text { Low salinity } \\
\text { alone }\end{array}$ & $\begin{array}{l}\text { High } \mathrm{NH}_{4}^{+} \\
\text {alone }\end{array}$ & $\begin{array}{l}\text { Expected additive } \\
\text { response }\end{array}$ & $\begin{array}{l}\text { Observed combined } \\
\text { response }\end{array}$ & Effect \\
\hline$P_{\max }$ & $\begin{array}{l}+26 \% \\
(-8,62)\end{array}$ & $\begin{array}{c}+217 \% \\
(111,347)\end{array}$ & $\begin{array}{c}+243 \% \\
(128,385)\end{array}$ & $\begin{array}{l}+25 \% \\
(-1,52)\end{array}$ & Neg. synergistic \\
\hline Respiration & $\begin{array}{c}+11 \% \\
(-104,144)\end{array}$ & $\begin{array}{c}-49 \% \\
(-107,40)\end{array}$ & $\begin{array}{c}+38 \% \\
(-186,156)\end{array}$ & $\begin{array}{c}+14 \% \\
(-77,123)\end{array}$ & Additive \\
\hline$F_{\mathrm{v}} / F_{\mathrm{m}}$ & $\begin{array}{c}-11 \% \\
(-16,-6)\end{array}$ & $\begin{array}{l}-1 \% \\
(-5,3)\end{array}$ & $\begin{array}{c}-12 \% \\
(-20,-4)\end{array}$ & $\begin{array}{c}-9 \% \\
(-20,-1)\end{array}$ & Additive \\
\hline LER & $\begin{array}{c}-69 \% \\
(-79,-56)\end{array}$ & $\begin{array}{c}+95 \% \\
(70,121)\end{array}$ & $\begin{array}{l}+26 \% \\
(-6,54)\end{array}$ & $\begin{array}{c}-86 \% \\
(-90,-82)\end{array}$ & Neg. synergistic \\
\hline IAR & $\begin{array}{l}-13 \% \\
(-36,8)\end{array}$ & $\begin{array}{l}+9 \% \\
(0,19)\end{array}$ & $\begin{array}{c}-3 \% \\
(-28,19)\end{array}$ & $\begin{array}{c}-36 \% \\
(-50,-20)\end{array}$ & Additive \\
\hline NP & $\begin{array}{c}-52 \% \\
(-66,-38)\end{array}$ & $\begin{array}{l}+31 \% \\
(9,56)\end{array}$ & $\begin{array}{c}-21 \% \\
(-51,13)\end{array}$ & $\begin{array}{c}-80 \% \\
(-94,-68)\end{array}$ & Neg. synergistic \\
\hline No. of leaves & $\begin{array}{l}-20 \% \\
(-34,-7)\end{array}$ & $\begin{array}{l}+11 \% \\
(7,15)\end{array}$ & $\begin{array}{c}-9 \% \\
(-25,8)\end{array}$ & $\begin{array}{c}-36 \% \\
(-41,-30)\end{array}$ & Neg. synergistic \\
\hline Necrosis & $\begin{array}{c}+622 \% \\
(229,1117)\end{array}$ & $\begin{array}{c}+160 \% \\
(-66,478)\end{array}$ & $\begin{array}{c}+782 \% \\
(253,1433)\end{array}$ & $\begin{array}{c}+830 \% \\
(317,1324)\end{array}$ & Additive \\
\hline Survival & $\begin{array}{l}-3 \% \\
(-7,0)\end{array}$ & $\begin{array}{c}0 \% \\
(0,0)\end{array}$ & $\begin{array}{l}-3 \% \\
(-7,0)\end{array}$ & $\begin{array}{c}-15 \% \\
(-21,-9)\end{array}$ & Neg. synergistic \\
\hline $\mathrm{NH}_{4}{ }^{+}$uptake rate & $\begin{array}{c}-51 \\
(-65,-31)\end{array}$ & $\begin{array}{c}-64 \\
(-83,-37)\end{array}$ & $\begin{array}{c}-115 \\
(-146,-74)\end{array}$ & $\begin{array}{c}-80 \\
(-88,-71)\end{array}$ & Additive \\
\hline $\mathrm{PO}_{4}{ }^{3-}$ uptake rate & $\begin{array}{c}+33 \% \\
(-44,127)\end{array}$ & $\begin{array}{c}+430 \% \\
(297,544)\end{array}$ & $\begin{array}{c}+464 \% \\
(289,644)\end{array}$ & $\begin{array}{l}+91 \% \\
(8,202)\end{array}$ & Neg. synergistic \\
\hline
\end{tabular}
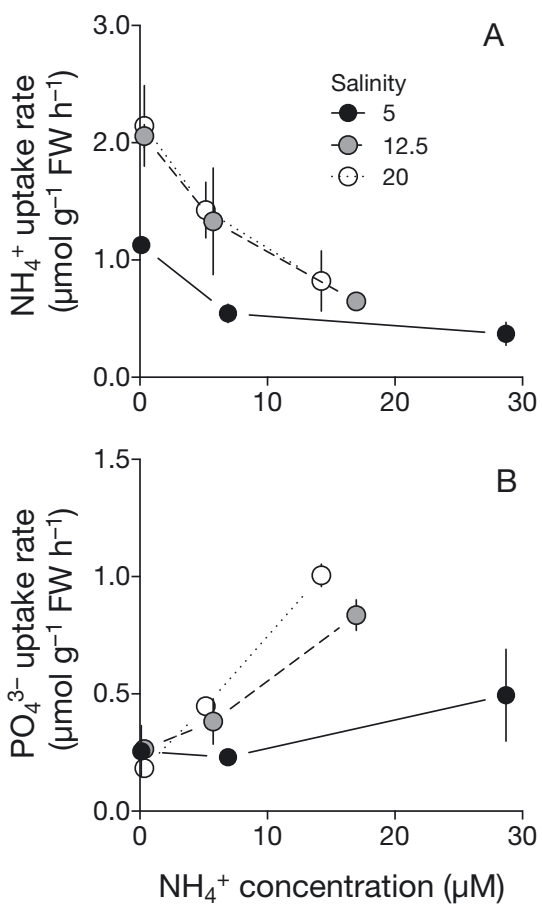

Fig. 2. Zostera marina. (A) $\mathrm{NH}_{4}{ }^{+}$and (B) $\mathrm{PO}_{4}{ }^{3-}$ uptake rates measured during the last week of the experiment on eelgrass plants exposed to 3 levels of salinity and 3 levels of $\mathrm{NH}_{4}{ }^{+}$. Values are means (across 3 replicate aquaria) $\pm 1 \mathrm{SE}$
$\mathrm{NH}_{4}{ }^{+}$treatment at salinity 5 . The $\mathrm{K}^{+}: \mathrm{Na}^{+}$-ratio (molar) was modified by both main factors (Table 4). The ratio decreased with increasing salinity and increased with $\mathrm{NH}_{4}{ }^{+}$enrichment at salinities 12.5 and 20, but remained largely similar at salinity 5 (Fig. 4D).

Sucrose concentrations were affected by $\mathrm{NH}_{4}{ }^{+}$ treatment and salinity and by the $\mathrm{NH}_{4}{ }^{+} \times$plant part interaction (Fig. 5A,B, Table 5). The sucrose content decreased with decreasing salinity and increasing $\mathrm{N}$ loading. The reduction in sucrose concentration with increasing $\mathrm{NH}_{4}{ }^{+}$was larger in leaves than in roots/ rhizomes. The starch content was one order of magnitude lower than the sucrose content (Fig. 5C,D). Starch content was affected significantly by all main factors (Table 5), being lower in roots/rhizomes than in leaves and decreasing with decreasing salinity. The starch content decreased generally with increasing $\mathrm{NH}_{4}{ }^{+}$-load.

\section{DISCUSSION}

Eelgrass is common and often abundant in estuarine habitats where it is exposed to natural and/or anthropogenic driven variations in salinity and 

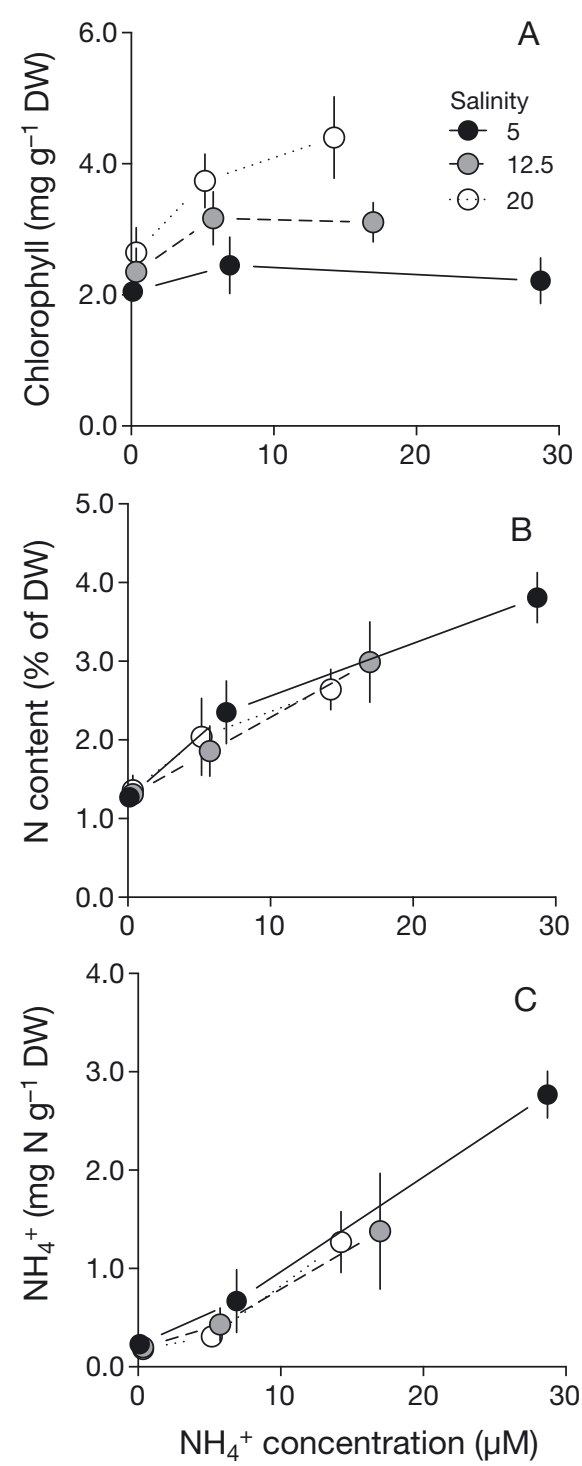

Fig. 3. Zostera marina. Chlorophyll content and $\mathrm{N}$ pools (total $\mathrm{N}$ and intracellular ammonium $\mathrm{N}$ ) in leaves of eelgrass plants exposed to 3 levels of salinity and 3 levels of $\mathrm{NH}_{4}{ }^{+}$: (A) chlorophyll $\mathrm{a}_{\mathrm{a}, \mathrm{b}}$, content; (B) total $\mathrm{N}$ content; (C) intracellular $\mathrm{NH}_{4}{ }^{+}$content. Values are means (across 3 replicate aquaria) $\pm 1 \mathrm{SE}$

nutrient availability. Our results showed that low salinity had a strong negative effect on eelgrass performance while increasing $\mathrm{NH}_{4}{ }^{+}$availability mostly had a positive effect on eelgrass variables related to growth and survival. Interestingly, the combined effect of low salinity and high $\mathrm{NH}_{4}{ }^{+}$availability turned the positive impact of high $\mathrm{NH}_{4}^{+}$ availability into a strong negative and, in most cases, synergetic effect as indicated from the significant interaction effects between salinity and $\mathrm{NH}_{4}{ }^{+}$ concentration.
Table 4. Results of multivariate and univariate permutational ANCOVA analyses examining the effects of salinity (S) (categorical variable) and ammonium concentration (N) (continuous variable) on chlorophyll content, total N content, ammonium content, the content of different ions $\left(\mathrm{Na}^{+}, \mathrm{K}^{+}, \mathrm{Cl}^{-}\right)$and the $\mathrm{K}^{+}: \mathrm{Na}^{+}$molar ratio in leaves of eel grass plants. Bold p-values indicate significant results $(\alpha=0.05)$

\begin{tabular}{|c|c|c|c|c|}
\hline Variable, factors & df & MS & Pseudo- $F$ & $\mathrm{p}$ \\
\hline \multicolumn{5}{|c|}{ Univariate responses } \\
\hline \multicolumn{5}{|c|}{ Chlorophyll content } \\
\hline $\mathrm{N}$ & 1 & $2.96 \times 10^{-2}$ & 5.98 & 0.024 \\
\hline $\mathrm{S}$ & 2 & $5.27 \times 10^{-2}$ & 10.63 & $<0.001$ \\
\hline $\mathrm{N} \times \mathrm{S}$ & 2 & $1.18 \times 10^{-2}$ & 2.38 & 0.114 \\
\hline Residual & 21 & $4.94 \times 10^{-3}$ & & \\
\hline \multicolumn{5}{|l|}{$\mathbf{N}$ pools } \\
\hline \multicolumn{5}{|l|}{ Total N content } \\
\hline $\mathrm{N}$ & 1 & 0.72 & 108.71 & $<0.001$ \\
\hline $\mathrm{S}$ & 2 & $2.05 \times 10^{-2}$ & 3.11 & 0.065 \\
\hline $\mathrm{N} \times \mathrm{S}$ & 2 & $8.84 \times 10^{-4}$ & 0.13 & 0.879 \\
\hline Residual & 21 & $6.60 \times 10^{-3}$ & & \\
\hline \multicolumn{5}{|c|}{ Ammonium content } \\
\hline $\mathrm{N}$ & 1 & 0.55 & 42.05 & $<0.001$ \\
\hline $\mathrm{S}$ & 2 & $2.16 \times 10^{-2}$ & 1.64 & 0.221 \\
\hline $\mathrm{N} \times \mathrm{S}$ & 2 & $6.07 \times 10^{-3}$ & 0.46 & 0.641 \\
\hline Residual & 21 & $1.31 \times 10^{-2}$ & & \\
\hline \multicolumn{5}{|l|}{ Ions } \\
\hline \multicolumn{5}{|l|}{$\mathrm{Na}^{+}$} \\
\hline $\mathrm{N}$ & 1 & $3.04 \times 10^{-3}$ & 1.76 & 0.195 \\
\hline $\mathrm{S}$ & 2 & 0.14 & 83.06 & $<0.001$ \\
\hline $\mathrm{N} \times \mathrm{S}$ & 2 & $4.52 \times 10^{-2}$ & 26.13 & $<0.001$ \\
\hline Residual & 21 & $1.73 \times 10^{-3}$ & & \\
\hline \multicolumn{5}{|l|}{$\mathbf{K}^{+}$} \\
\hline $\mathrm{N}$ & 1 & $4.15 \times 10^{-2}$ & 13.40 & 0.002 \\
\hline $\mathrm{S}$ & 2 & $1.71 \times 10^{-2}$ & 5.51 & 0.014 \\
\hline $\mathrm{N} \times \mathrm{S}$ & 2 & $6.94 \times 10^{-2}$ & 22.39 & $<0.001$ \\
\hline Residual & 21 & $3.10 \times 10^{-3}$ & & \\
\hline \multicolumn{5}{|l|}{$\mathrm{Cl}^{-}$} \\
\hline $\mathrm{N}$ & 1 & 0.15 & 19.45 & $<0.001$ \\
\hline $\mathrm{S}$ & 2 & 0.16 & 21.45 & $<0.001$ \\
\hline $\mathrm{N} \times \mathrm{S}$ & 2 & 0.11 & 14.69 & $<0.001$ \\
\hline Residual & 21 & $7.63 \times 10^{-3}$ & & \\
\hline \multicolumn{5}{|l|}{$\mathrm{K}^{+}: \mathrm{Na}^{+}$} \\
\hline $\mathrm{N}$ & 1 & $8.17 \times 10^{-3}$ & 5.44 & 0.030 \\
\hline $\mathrm{S}$ & 2 & $5.62 \times 10^{-2}$ & 37.43 & $<0.001$ \\
\hline $\mathrm{N} \times \mathrm{S}$ & 2 & $3.48 \times 10^{-3}$ & 2.31 & 0.124 \\
\hline Residual & 21 & $1.50 \times 10^{-3}$ & & \\
\hline
\end{tabular}

Eelgrass was only marginally affected by intermediate salinity (12.5 compared to 20 ) while exposure to low salinity (5) had a negative effect on most growthrelated variables. Hyposaline conditions led to reduced growth (lower leaf elongation, internode appearance and net production), shoots with fewer and more necrotic leaves, reduced nutrient uptake capacity and elevated mortality. Most of these responses were expected and largely similar to those reported from other studies on low salinity stress in eelgrass (e.g. Nejrup \& Pedersen 2008, Salo \& Peder- 

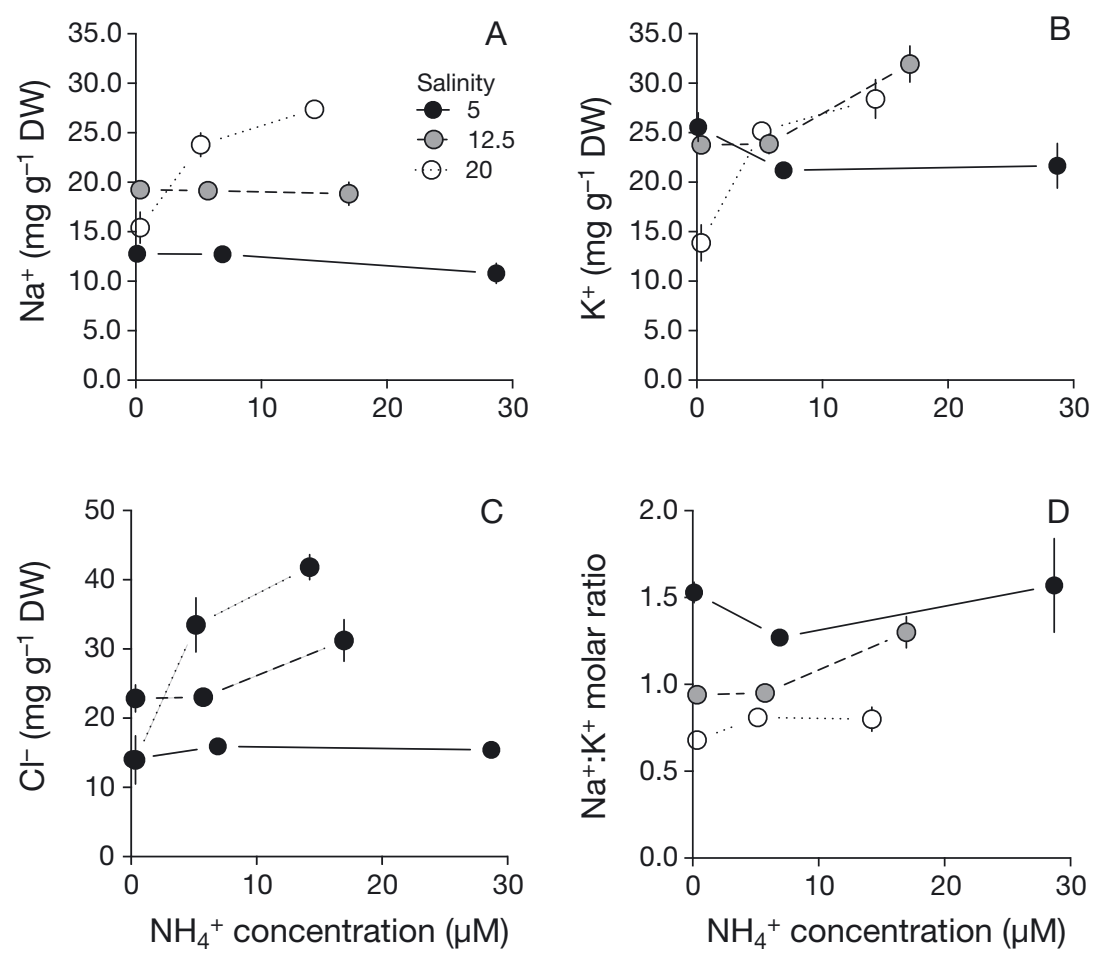

Fig. 4. Zostera marina. Intracellular concentrations of (A) $\mathrm{Na}^{+},(\mathrm{B}) \mathrm{K}^{+}$and (C) $\mathrm{Cl}^{-}$; and (D) $\mathrm{K}^{+}: \mathrm{Na}^{+}$molar ratio in leaves of eelgrass plants exposed to 3 levels of salinity and 3 levels of $\mathrm{NH}_{4}{ }^{+}$. Values are means (across 3 replicate aquaria) $\pm 1 \mathrm{SE}$

Table 5. Results of multivariate and univariate permutational ANCOVAs examining the effects of salinity (S) (categorical variable), plant tissue (Ti) (i.e. leaves or roots/rhizomes; categorical variable) and ammonium concentration $(\mathrm{N})$ (continuous variable) on sucrose and starch concentrations. Bold p-values indicate significant results $(\alpha=0.05)$

\begin{tabular}{|lrcrr|}
\hline $\begin{array}{l}\text { Variable, } \\
\text { factors }\end{array}$ & df & MS & Pseudo-F & \multicolumn{1}{c|}{$\mathrm{p}$} \\
\hline Sucrose & & & & \\
$\mathrm{N}$ & 1 & 1.54 & 128.33 & $\mathbf{< 0 . 0 0 1}$ \\
$\mathrm{S}$ & 2 & 0.50 & 41.71 & $\mathbf{< 0 . 0 0 1}$ \\
$\mathrm{Ti}$ & 1 & $4.41 \times 10^{-2}$ & 3.69 & 0.062 \\
$\mathrm{~N} \times \mathrm{S}$ & 2 & $6.28 \times 10^{-2}$ & 0.52 & 0.605 \\
$\mathrm{~N} \times \mathrm{T}$ & 1 & 0.15 & 12.64 & $<\mathbf{0 . 0 0 1}$ \\
$\mathrm{S} \times \mathrm{Ti}$ & 2 & $1.10 \times 10^{-2}$ & 0.92 & 0.410 \\
$\mathrm{~S} \times \mathrm{N} \times \mathrm{Ti}$ & 2 & $1.28 \times 10^{-2}$ & 1.07 & 0.361 \\
$\mathrm{Residual}$ & 42 & $1.20 \times 10^{-2}$ & & \\
$\mathrm{Starch}$ & & & & \\
$\mathrm{N}$ & 1 & 0.30 & 37.85 & $\mathbf{< 0 . 0 0 1}$ \\
$\mathrm{S}$ & 2 & 0.13 & 16.07 & $<\mathbf{0 . 0 0 1}$ \\
$\mathrm{Ti}$ & 1 & 0.21 & 27.26 & $<\mathbf{0 . 0 0 1}$ \\
$\mathrm{N} \times \mathrm{S}$ & 2 & $6.99 \times 10^{-5}$ & $8.90 \times 10^{-3}$ & 0.991 \\
$\mathrm{~N} \times \mathrm{T}$ & 1 & $1.80 \times 10^{-2}$ & 2.29 & 0.134 \\
$\mathrm{~S} \times \mathrm{Ti}$ & 2 & $1.04 \times 10^{-2}$ & 1.33 & 0.283 \\
$\mathrm{~S} \times \mathrm{N} \times \mathrm{Ti}$ & 2 & $1.55 \times 10^{-2}$ & 1.98 & 0.151 \\
Residual & 42 & $7.86 \times 10^{-3}$ & & \\
\hline
\end{tabular}

sen 2014, Salo et al. 2014). The negative effect of low salinity on growth, nutrient uptake and survival may have been caused by cell damages due to inappropriate osmoregulation (e.g. cell rupture, changes in ion composition and $\mathrm{pH}$, disturbance of inner membranes), reduced photosynthetic capacity and/or by increasing metabolic costs related to osmoregulation. The photosynthetic apparatus is often considered one of the most sensitive components in plant cells (Maxwell \& Johnson 2000). The marked decrease in pigment concentration (20 to $50 \%$ ) in low salinity plants seemed to support this expectation at first, but gross photosynthetic rates (i.e. $P_{\max }$ ) remained largely unaffected by salinity unless plants were simultaneously exposed to high levels of $\mathrm{NH}_{4}{ }^{+}$. Also, $F_{\mathrm{v}} / F_{\mathrm{m}}$ was only marginally $(<10 \%)$ reduced at low salinity and values remained within those considered typical for unstressed plants (i.e. 0.8; Björkman \& Demmig 1987, Johnson et al. 1993). In other words, reduced photosynthetic efficiency could not explain the negative effect that low salinity had on growth and survival.

Low salinity had a negative effect on the uptake capacity of $\mathrm{NH}_{4}{ }^{+}$and $\mathrm{PO}_{4}{ }^{3-}$ and the relative effect of low salinity remained largely the same across all levels of the N-treatment (i.e. no interaction between salinity and $\mathrm{NH}_{4}{ }^{+}$). The correlation between net uptake of $\mathrm{NH}_{4}{ }^{+}$and $\mathrm{PO}_{4}{ }^{3-}$ and salinity may have been caused by the active export of ions during osmoregulation and/or by increased competition for energy that could affect active nutrient uptake across the plasma membrane (in case of $\mathrm{PO}_{4}{ }^{3-}$ ) and/or the assimilation of $\mathrm{NH}_{4}{ }^{+}$and $\mathrm{PO}_{4}{ }^{3-}$ (McGlathery et al. 1996, Touchette 2007, Garrote-Moreno et al. 2015). Hyposaline conditions caused a net loss of $\mathrm{Na}^{+}, \mathrm{K}^{+}$ and $\mathrm{Cl}^{-}$from eelgrass and lead to a marked increase in $\mathrm{K}^{+}: \mathrm{Na}^{+}$ratios, indicating unbalanced, disturbed ionic conditions in the plants (Kirst 1990, Touchette 2007, Choi et al. 2010). Osmoregulation is related to increased metabolic costs and respiration almost doubled with decreasing salinity (independently of $\mathrm{N}$-treatment). At the same time $\mathrm{C}$ reserves in low salinity plants were reduced by ca. $50 \%$ over the course of the experiment. The concomitant increase in respiration and elevated mobilization of stored $\mathrm{C}$ 

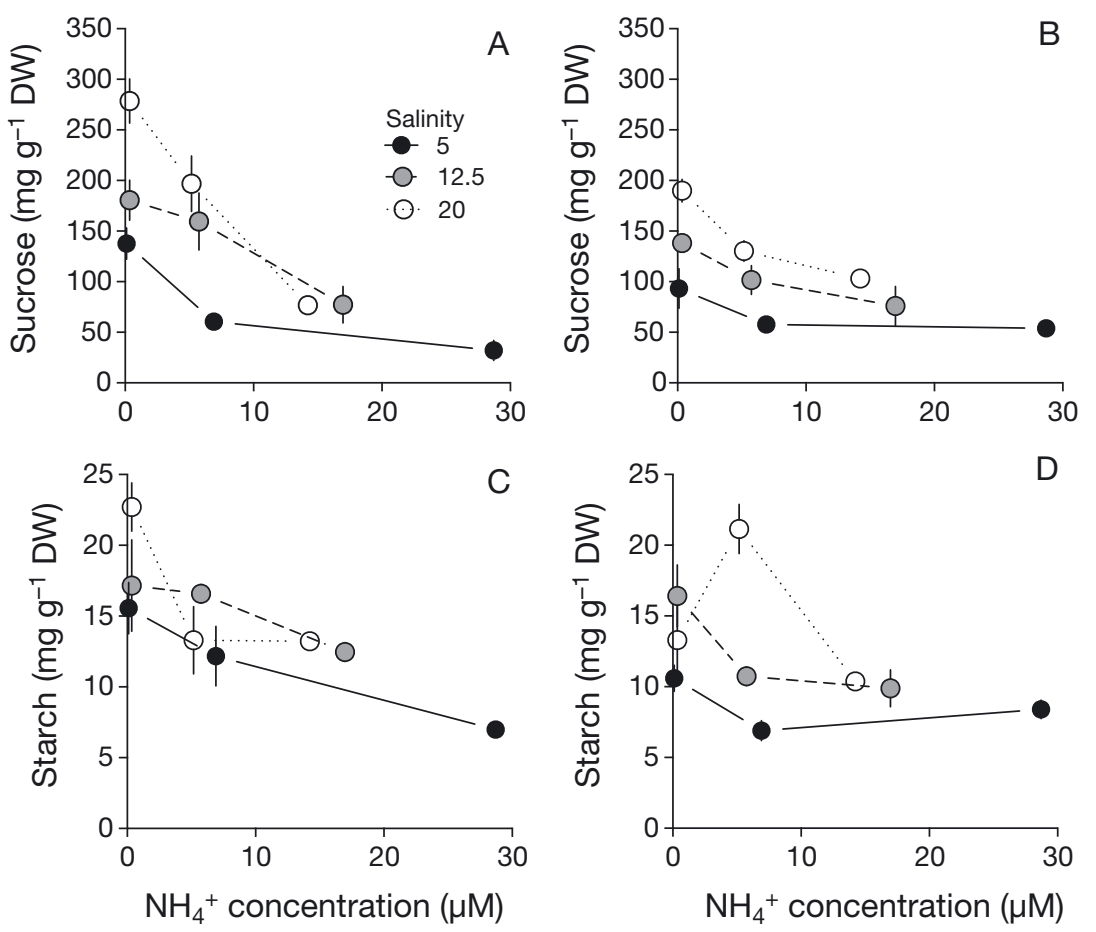

Fig. 5. Zostera marina. Sucrose concentration in (A) leaves, and (B) roots/ rhizomes, and starch content in (C) aboveground (i.e. leaves) and (D) belowground (i.e. roots/rhizomes) tissues in eelgrass plants exposed to 3 levels of salinity and 3 levels of $\mathrm{NH}_{4}^{+}$. Values are means (across replicate aquaria) $\pm 1 \mathrm{SE}$

suggests that exposure to low salinity was related to a substantial increase in the cost of osmoregulation and/or the repair of damages and that photosynthesis was unable to cover these elevated energy requirements.

Exposure to elevated levels of nitrogen and, especially, to $\mathrm{NH}_{4}{ }^{+}$can be both beneficial and disadvantageous to seagrasses depending on the nutrient status of the plants. Positive effects (e.g. increased photosynthesis and growth) are often seen in nutrient-poor environments where plants may be $\mathrm{N}$ limited (Touchette \& Burkholder 2000). A number of studies have, however, shown that even relatively low concentrations of $\mathrm{NH}_{4}{ }^{+}$can have an adverse effect on eelgrass (van Katwijk et al. 1997, Villazán et al. 2013b). These effects can either be due to direct toxic effects of $\mathrm{NH}_{4}{ }^{+}$, or be due to increased energy requirements driven by elevated assimilation of $\mathrm{NH}_{4}{ }^{+}$into amino acids and proteins (Brun et al. 2002, 2008, Villazán et al. 2013b). $\mathrm{N}$ assimilation requires energy and carbon skeletons, which must be provided by photosynthesis or mobilized from $\mathrm{C}$ reserves within the plant (Marschner 1995). Villazán et al. (2013b) demonstrated that $\mathrm{NH}_{4}{ }^{+}$enrichment has a positive effect on eelgrass fitness as long as light conditions are kept sufficient, but that exposure to similar $\mathrm{NH}_{4}{ }^{+}$levels under low light conditions results in exhaustion of internal $\mathrm{C}$ stores and reduced plant performance. This relationship indicates that $\mathrm{N}$ assimilation competes with other metabolic process for $\mathrm{C}$ and energy and that long-term exposure to elevated $\mathrm{NH}_{4}{ }^{+}$levels may affect the $\mathrm{C}$ balance in seagrasses. Thus, the simultaneous exposure to high $\mathrm{NH}_{4}{ }^{+}$ availability and an additional stressor is therefore likely to lead to a negative effect of $\mathrm{NH}_{4}{ }^{+}$on plant performance as has been previously demonstrated in Zostera noltei (Brun et al. 2008, La Nafie et al. 2012).

Exposure of eelgrass to high levels of $\mathrm{NH}_{4}^{+}$at ambient salinity (20) had an overall positive effect on plant performance. Photosynthesis, growth and $\mathrm{P}$ uptake rate were stimulated while $\mathrm{N}$ uptake rate was reduced and mortality remained unaffected by $\mathrm{N}$ treatment as long as salinity was kept high. The positive effect of $\mathrm{NH}_{4}{ }^{+}$enrichment may have been caused by low DIN concentrations in the water used for our control treatment (Table 1), which may have left plants from this treatment slightly $\mathrm{N}$ limited. The total $\mathrm{N}$ content in plants from the control treatment was close to the limiting level for seagrasses $(1.2$ to $1.3 \% \mathrm{~N}$ of DW; Duarte 1990) by the end of the experiment and $\mathrm{N}$ enrichment may therefore have released plants from $\mathrm{N}$ limitation in the $+\mathrm{N}$ and $+\mathrm{NN}$ treatments. The positive effect of $\mathrm{NH}_{4}{ }^{+}$enrichment on growth was, however, also followed by a significant accumulation of intracellular $\mathrm{NH}_{4}{ }^{+}$, which may be the major reason why $\mathrm{N}$ uptake rates were reduced at low salinity. Nutrient uptake rates are controlled by the external concentration of nutrients, but also by the nutrient quota within the plant and high internal concentrations of $\mathrm{NH}_{4}{ }^{+}$may exert a negative feedback on $\mathrm{N}$ uptake rates in algae and seagrasses (e.g. Pedersen 1994, McGlathery et al. 1996, Pedersen et al. 1997). The uptake of $\mathrm{PO}_{4}{ }^{3-}$ was, in contrast, stimulated by $\mathrm{NH}_{4}^{+}$enrichment. Increasing the $\mathrm{N}$ quota in N-enriched plants would typically lead to higher protein and enzyme levels (e.g. Villazán et al. 2013b), which could stimulate active uptake and assimilation of $\mathrm{PO}_{4}{ }^{3-}$.

The positive effect of $\mathrm{N}$ enrichment on eelgrass performance was followed by a 50 to $60 \%$ reduction 
in the content of sucrose and starch. This reduction indicates that photosynthesis, although stimulated by $\mathrm{N}$ enrichment, was unable to cover the energy and $\mathrm{C}$ demand related to increasing $\mathrm{N}$ assimilation and, thus, that competition for $\mathrm{C}$ and energy would have intensified and potentially have become harmful to the plants if they had been exposed to these conditions beyond the experimental period of $4 \mathrm{wk}$.

The positive effect of high $\mathrm{N}$ availability that we observed at high salinity was completely reversed when plants were exposed to low salinity. Only few studies have assessed the potential interaction effect between high $\mathrm{NH}_{4}{ }^{+}$availability and low or high salinity in seagrasses, but Kahn \& Durako (2006) showed that the combination of high $\mathrm{NH}_{4}{ }^{+}$availability and low salinity impairs in situ growth of Thalassia testudinum while van Katwijk et al. (1999) found that exposure of eelgrass to hypersaline conditions (salinity 30 as opposed to 23) leads to increasingly negative effects of high nutrient availability on eelgrass.

The combined effects of high $\mathrm{NH}_{4}{ }^{+}$availability and low salinity on eelgrass performance were largely the same as the individual effects of low salinity, i.e. reduced growth, reduced shoot size, more necrotic leaves, lower nutrient uptake rates and elevated mortality, but the responses were in most cases much stronger than when exposed to low salinity alone, and also stronger than the algebraic sum of the individual response to low salinity and high $\mathrm{NH}_{4}{ }^{+}$availability, respectively (Table 3). A combined response of 2 stressors that is larger than the sum of the individual responses is a strong indication of a synergistic effect. All growth-related response variables in Table 3 , except for $R_{\mathrm{D}}, F_{\mathrm{v}} / F_{\mathrm{m}}, \mathrm{IAR}$, necrosis and $\mathrm{N}$ uptake rate, had combined responses that were substantially larger than the sum of the 2 individual responses, underlining that simultaneous exposure to low salinity and high $\mathrm{NH}_{4}{ }^{+}$availability had an overall negative synergistic effect on eelgrass.

The underlying mechanisms behind an interaction between $\mathrm{NH}_{4}^{+}$enrichment and low or high salinity are not well understood. We suggest that the interaction effects are caused by a combination of the physical and chemical cell damages imposed by low salinity and high internal $\mathrm{NH}_{4}{ }^{+}$concentrations, respectively, combined with an enhanced competition between $\mathrm{NH}_{4}{ }^{+}$assimilation and osmoregulatory processes for energy and carbon skeletons. Any physical and/or chemical damages require energy for repair processes and low salinity may thus increase the demand for energy needed for osmoregulation while at the same time it may lower $\mathrm{C}$ fixation through photosynthesis. High $\mathrm{NH}_{4}{ }^{+}$availability increases the need for energy to support assimilation of $\mathrm{NH}_{4}{ }^{+}$. These energy-consuming processes will likely divert energy away from other important metabolic processes (repair, growth etc.), which may impair the carbon balance within plants and consequently reduce plant growth and ultimately increase mortality. Thus, any factor that increases the demand for energy and interacts with low salinity and/or $\mathrm{NH}_{4}{ }^{+}$ enrichment, e.g. high temperature (Salo \& Pedersen 2014), low irradiance (Villazán et al. 2013b, Jiang et al. 2013) or hydrodynamics (La Nafie et al. 2012), may amplify the negative effects of these stressors.

We examined the physiological responses of eelgrass to combinations of salinity and $\mathrm{NH}_{4}{ }^{+}$enrichment, and tested these interactions at steady state levels of stress for $4 \mathrm{wk}$. The amount of stress is equal to the product of its intensity and duration (Schulze et al. 2005) and short-term exposure to stressful levels of salinity and $\mathrm{NH}_{4}{ }^{+}$should thus lead to less severe effects. Future studies should evaluate the response to unfavorable levels of salinity and $\mathrm{NH}_{4}{ }^{+}$as a function of exposure time and, also, include studies on the potential recovery after exposure to stressful conditions (i.e. resilience) to fully evaluate the consequences of changes in salinity and $\mathrm{NH}_{4}{ }^{+}$at several time scales.

Eelgrass habitats that experience low salinity and relatively high concentrations of $\mathrm{NH}_{4}{ }^{+}$are common in inner parts of estuaries, in shallow sheltered bays and/or close to river mouths. Most climate models predict an increased frequency and intensity of rainfall along the northern Atlantic coast of Europe as a result of ongoing climate changes (IPCC 2013). More intense and frequent precipitation events will increase the seaward transport of freshwater and dissolved nutrients from catchments and especially those dominated by agricultural areas (Meier et al. 2012). Since low salinity combined with high levels of $\mathrm{NH}_{4}{ }^{+}$has negative additive or synergistic effects on estuarine seagrasses, seagrass populations are at risk of experiencing an increased level of stress in the future. The occurrence of synergistic responses to multiple stressors should therefore be taken into account in the future management of coastal areas.

Acknowledgements. Support was provided by the Spanish national projects CTM2008-00012 (iMacHydro) and CTM2011-24482 (SEA-LIVE). B.V. was supported by a FPI grant from Ministerio de Economía y Competitividad while T.S. and M.F.P. were supported by Roskilde University and the REELGRASS (09-063190/DSF) project. We thank the 3 anonymous referees for constructive comments. Thanks to R. Guttesen and A. Faarborg for valuable help with the chemical analyses. This is CEIMAR journal publication no. 107. 


\section{LITERATURE CITED}

Alcoverro T, Romero J, Duarte CM, López NI (1997) Spatial and temporal variations in nutrient limitation of seagrass Posidonia oceanica growth in the NW Mediterranean. Mar Ecol Prog Ser 146:155-161

Anderson MJ, Gorley RN, Clarke KR (2008) PERMANOVA+ for PRIMER. Guide to software and statistical methods. PRIMER-E Ltd., Plymouth

> Björkman O, Demmig B (1987) Photon yield of $\mathrm{O}_{2}$ evolution and chlorophyll fluorescence at $77 \mathrm{~K}$ among vascular plants of diverse origins. Planta 170:489-504

$>$ Borum J, Pedersen O, Greve TM, Frankovich TA, Zieman JC, Fourqurean JW, Madden CJ (2005) The potential role of plant oxygen and sulphide dynamics in die-off events of the tropical seagrass, Thaliassia testudinum. J Ecol 93:148-158

- Bower CE, Holm-Hansen T (1980) A salicylate-hypochlorite method for determining ammonia in seawater. Can J Fish Aquat Sci 37:794-798

Britto DT, Kronzucher HJ (2002) $\mathrm{NH}_{4}{ }^{+}$toxicity in higher plants: a critical review. J Plant Physiol 159:567-584

> Brun FG, Hernández I, Vergara JJ, Peralta G, Pérez-Lloréns JL (2002) Assessing the toxicity of ammonium pulses to the survival and growth of Zostera noltii. Mar Ecol Prog Ser 225:177-187

> Brun FG, Vergara JJ, Navarro G, Hernández I, PérezLloréns JL (2003) Effect of shading by Ulva rigida canopies on growth and carbon balance of the seagrass Zostera noltii. Mar Ecol Prog Ser 265:85-96

> Brun FG, Olivé I, Malta E, Vergara JJ, Hernández I, PérezLloréns JL (2008) Increased vulnerability of Zostera noltii to stress caused by low light and elevated ammonium levels under phosphate deficiency. Mar Ecol Prog Ser 365:67-75

> Burkholder JM, Mason KM, Glasgow HB Jr (1992) Watercolumn nitrate enrichment promotes decline of eelgrass Zostera marina: evidence from seasonal mesocosm experiments. Mar Ecol Prog Ser 81:163-178

Burkholder JM, Glasgow HB Jr, Cooke JE (1994) Comparative effects of water-column nitrate enrichment on eelgrass Zostera marina, shoalgrass Halodule wrightii, and widgeongrass Ruppia maritima. Mar Ecol Prog Ser 105: 121-138

Choi TS, Kang EJ, Kim J, Kim KY (2010) Effect of salinity on growth and nutrient uptake of Ulva pertusa (Chlorophyta) from an eelgrass bed. Algae 25:17-26

Chollett I, Bone D, Pérez D (2007) Effects of heavy rainfall on Thalassia testudinum beds. Aquat Bot 87:189-195

> Darling ES, Côté IM (2008) Quantifying the evidence for ecological synergies. Ecol Lett 11:1278-1286

den Hartog C (1970) The seagrasses of the world. North Holland, Amsterdam

Duarte CM (1990) Seagrass nutrient content. Mar Ecol Prog Ser 67:201-207

> Efron B, Tibshirani R (1986) Bootstrap methods for standard errors, confidence intervals, and other measures of statistical accuracy. Stat Sci 1:54-77

Garrote-Moreno A, McDonald A, Sherman TD, SánchezLizaso JL, Heck KL Jr, Cebrián J (2015) Short-term impacts of salinity pulses on ionic ratios of the seagrasses Thalassia testudinum and Halodule wrightii. Aquat Bot 120:315-321

- Hellebusi JA (1976) Osmoregulation. Annu Rev Plant Physiol 27:485-505
Holmer M, Bondgaard EJ (2001) Photosynthesis and growth response of eelgrass to low oxygen and high sulfide concentrations during hypoxic events. Aquat Bot 70:29-38

Howarth RW, Billen G, Swaney D, Townsend A and others (1996) Regional nitrogen budgets and riverine $\mathrm{N}$ and $\mathrm{P}$ fluxes for the drainages to the Atlantic ocean: natural and human influences. Biogeochemistry 35:75-139

IPCC (2013) Climate change 2013: the physical science basis. Contribution of Working Group I to the Fifth Assessment Report of the Intergovernmental Panel on Climate Change. Cambridge University Press, Cambridge

> Irlandi E, Orlando B, Maciá S, Biber P, Jones T, Kaufman L, Patterson ET (2002) The influence of freshwater runoff on biomass, morphometrics, and production of Thalassia testudinum. Aquat Bot 72:67-78

Jiang Z, Huang X, Zhang J (2013) Effect of nitrate enrichment and salinity reduction on the seagrass Thalassia hemprichii previously grown in low light. J Exp Mar Biol Ecol 443:114-122

> Johnson GN, Young AJ, Scholes JP, Horton P (1993) The dissipation of excess excitation energy in British plant species. Plant Cell Environ 16:673-679

Kahn AE, Durako MJ (2006) Thalassia testudinum seedling responses to changes in salinity and nitrogen levels. J Exp Mar Biol Ecol 335:1-12

Karsten (2012) Seaweed acclimation to salinity and desiccation stress. In: Wiencke C, Bischof K (eds) Seaweed biology: novel insights into ecophysiology, ecology and utilization. Springer, Berlin, p 87-107

Kirst GO (1990) Salinity tolerance of eukaryotic marine algae. Annu Rev Plant Physiol Plant Mol Biol 41:21-53

> La Nafie YA, de los Santos CB, Brun FG, van Katwijk MM, Bouma TJ (2012) Waves and high nutrient loads jointly decrease survival and separately affect morphological and biomechanical properties in the seagrass Zostera noltii. Limnol Oceanogr 57:1664-1672

Lyons DA, Mant RC, Bulleri F, Kotta J, Rilov G, Crowe TP (2012) What are the effects of macroalgal blooms on the structure and functioning of marine ecosystems? Systematic review protocol. Environmental Evidence 1:7

- Marín-Guirao L, Sandoval-Gil JM, Bernardeau-Esteller J, Ruíz JM, Sánchez-Lizaso JL (2013) Responses of the Mediterranean seagrass Posidonia oceanica to hypersaline stress duration and recovery. Mar Environ Res 84: 60-75

Marschner H (1995) The mineral nutrition of higher plants, 2nd edn. Academic Press, London

Maxwell K, Johnson GN (2000) Chlorophyll fluorescencea practical guide. J Exp Bot 51:659-668

McGlathery KJ (2001) Macroalgal blooms contribute to the decline of seagrass in nutrient-enriched coastal waters. J Phycol 37:453-456

> McGlathery KJ, Pedersen MF, Borum J (1996) Changes in intracellular nitrogen pools and feedback controls on nitrogen uptake in Chaetomorpha linum (Clorophyta). J Phycol 32:393-401

Meier HEM, Müller-Karulis B, Andersson HC, Dieterich C and others (2012) Impact of climate change on ecological quality indicators and biochemical fluxes in the Baltic Sea: a multi-model ensemble study. Ambio 41:558-573

> Meyer JS, Ingersoll CG, McUonald LL, Boyce MS (1986) Estimating uncertainty in population growth rates: jackknife vs. bootstrap techniques. Ecology 67:1156-1166

Murphy J, Riley JP (1962) A modified single-solution method for the determination of phosphate in natural 
waters. Anal Chim Acta 27:31-36

Myers N (1995) Environmental unknowns. Science 269: 358-360

> Nejrup LB, Pedersen MF (2008) Effects of salinity and water temperature on the ecological performance of Zostera marina. Aquat Bot 88:239-246

Olesen B, Sand-Jensen K (1993) Seasonal acclimatization of eelgrass Zostera marina growth to light. Mar Ecol Prog Ser 94:91-99

Olivé I, García-Sánchez MP, Brun FG, Vergara JJ, PérezLloréns JL (2009) Interactions of light and organic matter under contrasting resource simulated environments: the importance of clonal traits in the seagrass Zostera noltii. Hydrobiologia 629:199-208

Paine RT, Tegner MJ, Johnson EA (1998) Compounded perturbations yield ecological surprises. Ecosystems 1: 535-545

> Pedersen MF (1994) Transient ammonium uptake in the macroalgae Ulva lactuca (Chlorophyta): nature, regulation, and the consequences for choice of measuring technique. J Phycol 30:980-986

> Pedersen MF, Paling EI, Walker DI (1997) Nitrogen uptake and allocation in the seagrass Amphibolis antarctica. Aquat Bot 56:105-117

Perez M, Duarte CM, Romero J, Sand-Jensen K, Alcoverro T (1994) Growth plasticity in Cymodocea nodosa stands: the importance of nutrient supply. Aquat Bot 47:249-264

> Pérez M, Invers O, Ruiz JM, Frederiksen MS, Holmer M (2007) Physiological responses of the seagrass Posidonia oceanica to elevated organic matter content in sediments: an experimental assessment. J Exp Mar Biol Ecol 344:149-160

Powell GVN, Kenworthy WJ, Fourqurean JW (1989) Experimental evidence for nutrient limitation of seagrass growth in a tropical estuary with restricted circulation. Bull Mar Sci 44:324-340

Quinn GP, Keough MJ (2002) Experimental design and data analysis for biologists. Cambridge University Press, Cambridge

Rudnick DT, Ortner PB, Browder JA, Davis SM (2005) A conceptual model of Florida Bay. Wetlands 25:870-883

Salo T, Pedersen MF (2014) Synergistic effects of altered salinity and temperature on estuarine eelgrass (Zostera marina) seedlings and clonal shoots. J Exp Mar Biol Ecol 457:143-150

Salo T, Pedersen MF, Boström C (2014) Population specific salinity tolerance in eelgrass (Zostera marina). J Exp Mar Biol Ecol 461:425-429

Sand-Jensen K (1975) Biomass, net production and growth dynamics in an eelgrass (Zostera marina L.) population in Vellerup Vig, Denmark. Ophelia 14:185-201

Editorial responsibility: Kenneth Heck,

Dauphin Island, Alabama, USA
Sand-Jensen K, Borum J (1991) Interactions among phytoplankton, periphyton, and macrophytes in temperate freshwaters and estuaries. Aquat Bot 41:137-175

Sand-Jensen K, Gordon DM (1984) Differential ability of marine and freshwater macrophytes to utilize $\mathrm{HCO}_{3}{ }^{-}$and $\mathrm{CO}_{2}$. Mar Biol 80:247-253

Sandoval-Gil JM, Ruiz JM, Marín-Guirao L, BernadeauEsteller J, Sánchez-Lizaso JL (2014) Ecophysiological plasticity of shallow and deep populations of the Mediterranean seagrasses Posidonia oceanica and Cymodocea nodosa in response to hypersaline stress. Mar Environ Res 95:39-61

Schulze ED, Beck E, Muller-Hohenstein K (2005) Plant ecology. Springer, Berlin

Short FT (1987) Effects of sediment nutrients on seagrasses: literature review and mesocosm experiment. Aquat Bot 27:41-57

Short FT, Dennison WC, Capone DG (1990) Phosphoruslimited growth of the tropical seagrass Syringodium filiforme in carbonate sediments. Mar Ecol Prog Ser 62: 169-174

Short FT, Carruthers T, Dennison W, Waycott M (2007) Global seagrass distribution and diversity: a bioregional model. J Exp Mar Biol Ecol 350:3-20

Touchette BW (2007) Seagrass-salinity interactions: physiological mechanisms used by submersed marine angiosperms for a life at sea. J Exp Mar Biol Ecol 350:194-215

> Touchette BW, Burkholder J (2000) Review of nitrogen and phosphorus metabolism in seagrasses. J Exp Mar Biol Ecol 250:133-167

van Katwijk MM, Vergeer LHT, Schmitz GHW, Roelofs JGM (1997) Ammonium toxicity in eelgrass Zostera marina. Mar Ecol Prog Ser 157:159-173

van Katwijk MM, Schmitz GHW, Gasseling AP, van Avesaath PH (1999) Effects of salinity and nutrient load and their interaction on Zostera marina. Mar Ecol Prog Ser 190:155-165

> Villazán B, Brun FG, Jiménez-Ramos R, Pérez-Loréns JL, Vergara JJ (2013a) Interaction between ammonium and phosphate uptake rates in the seagrass Zostera noltii. Mar Ecol Prog Ser 488:133-143

Villazán B, Pedersen MF, Brun FG, Vergara JJ (2013b) Elevated ammonium concentrations and low light form a dangerous synergy for eelgrass Zostera marina. Mar Ecol Prog Ser 493:141-154

Wintermans JFGM, De Mots A (1965) Spectrophotometric characteristics of chlorophylls $\mathrm{a}$ and $\mathrm{b}$ and their pheophytins in ethanol. Biochim Biophys Acta 109:448-453

Zieman JC (1975) Seasonal variation of turtle grass, Thalassia testudinum König with reference to temperature and salinity effects. Aquat Bot 1:107-122

Submitted: January 27, 2015; Accepted: July 20, 2015

Proofs received from author(s): September 6, 2015 